\section{Solar energy: bonanza or bunfight?}

\section{David Dickson describes the background to President Carter's announcement of a major boost to the US solar energy effort}

$\mathbf{O}$ $\mathrm{NE}$ of the biggest mistakes that President Jimmy Carter has made in 1978 has turned out to be a relatively small item in the proposed 1979 budget for the Department of Energy submitted to Congress in January. This was the suggestion that the amount of money allocated to research and development of solar technologies should be reduced from $\$ 411$ million in 1978 to $\$ 400$ million in 1979 .

At the time the administration justified this reduction on the grounds that many solar developments had reached the stage at which they could be successfully taken up by private industry. I.ater, department officials added that they had expected the solar R \& D budget to be substantially increased by Congress anyway, as had happened in previous years.

But the damage had been done. Environmentalists, concerned at the president's equivocal stand on nuclear energy, pointed to the reduced solar budget as a clear betrayal of campaign promises. And their messagc spread. An opinion poll recently found that $80 \%$ of those interviewed felt the government should be doing more research into solar technologies (compared to less than half for nuclear technologies). And the reduction of the solar R \& D budget is now widely quoted among those who had previously been Carter supporters as a reason for their disillusionment with his performance.

The statement which Carter was due to give yesterday as part of the international 'Sun-day' activities-and symbolically presented at the site of the new Solar Energy Research Institute near Denver in Colarado-therefore had a dual purpose. Not merely was the president keen to correct the impression that his administration is antisolar, he also had one eye firmly on Edmund (Jerry) Brown, Governor of California and a potential rival for the 1980 presidential nomination, who is leading his state towards a solar future.

In his Sun-day speech Carter was expected to reflect the growing enthusiasm for solar energy among the American people, for many of whom the promise of a clean and renewable cnergy resource lacking the waste problems of nuclear or fossil fucls now exerts a strong, almost mystical, attraction. This enthusiasm is itself reflected in the activities of two separate Washington-based coalitions both of which embrace a range of political positions and interests in focusing on the promotion of solar energy.
Sun-day itself has been organised through a wide range of groups sharing interests in environmental matters, and is largely the brainchild of Denis Hayes, organiser of the highly-successful 'Earth day' in 1970 which played an important part in injecting the word ecology into the national vocabulary. The second grouping, less publicised but equally influential, is known as the 'solar coalition', a movement that started primarily among congressional aides and has put together a package of energy bills which, as the result of rapidly increasing interest in recent months, is now claimed to have the support of almost a quarter of the members of Congress.

While both of these coalitions have been applying external pressure within the adminstration itself the main push for a strong initiative on solar energy has come from the Council on Environmental Quality. Drawing on a number of sources and analyses, such as Amory Lovins's Soft Energy Paths and Denis Haye's book Rays of Hope, the CEQ has recently produced a report in which it claims that, given sufficient national effort, the US could meet up to one quarter of its energy needs through solar technology by 2000 .

Largely at the initiative of the CEQ the president's domestic council subsequently drew up a proposal for a new solar strategy, including both shortterm projects and a full-scale review of federal activities in the solar area. These formed the basis for the proposals which the president was expected to present yesterday.

\section{A political issue}

But given that the administration now seems prepared to make an extra commitment though not as large as some would like-to solar encrgy, the central question is now not whether the development of solar technologies will take place, but in what direction. As the president's manouevrings indicate, the whole issue of solar energy has become overtly political, and the questions it begs are no longer merely technical, but economic and social as well. And it is the shifting balance between different types of judgement that have given rise to deep splits within government bodies on how a solar development programme should be pursued.

Until a few years ago, for example, the Department of Energy had shown a general scepticism towards the potential of solar energy. More recently this has given way to the realisation that solar

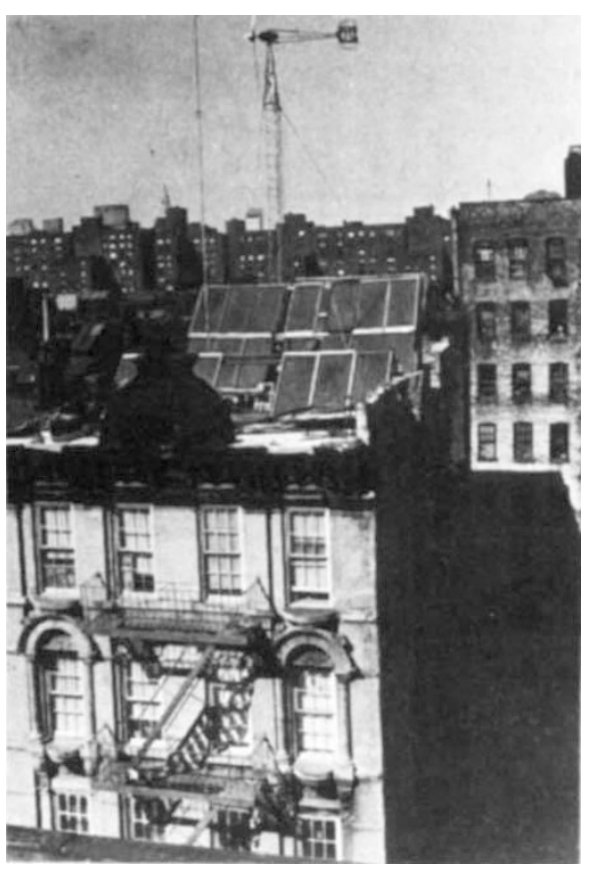

Consolidated Edison's windmill on top of a tenement building in New York

energy could become a viable addendum to a nuclear programme. Initially, however, DOE programmes were developed according to the same philosophy as had been used for fossil and nuclear fuels, namely that the most efficient and effective power production involved large centralised facilities, and that a development programme should head towards these by building up from small-scale demonstration plants. Two examples of this which gained early support have been the powertower concept, which involves a large array of mirrors all reflecting solar rays on to a central receiver, and the scheme for obtaining energy from the thermal gradient in the oceans (OTEC).

Further shifts have subsequently taken place, partly under pressure from Congress, leading the department to take an increasingly active interest in areas such as photovoltaics, windpower and biomass. And the greater divergence these have involved from the nuclear power development philosophy, the greater have been the organisational strains as the department has attempted to adapt.

Similar problems are being experienced by the utility companies charged with the responsibility of delivering power to consumers. Many of these, like the DOE, were initially highly sceptical of solar energy. And as they have been brought round to accepting it, the tendency has been to concentrate on centralised, capital-intensive facilities. Two concerns in particular have been voiced by the utility companies. The first is that the transition to solar should proceed in an orderly manner, taking into account existing systems and modes of operation. The second 
concern is with utility rates. Many utilities, for example, argue that the need to continue to provide back-up facilities for those times when solar energy is not available will not merely mean no reduction in electricity prices, but could even increase them by distorting the load patterns for which existing rates have been developed. Related to this is the fear that a decentralised power source could threaten the position of the utility companies. In a recent Manhattan court case the utility company Consolidated Edison was ordered by the New York public service commission to buy back the extra power generated on particularly windy days by a large windmill constructed on the roof of a renovated tenement building.

\section{New solar institutions}

Another institution that has found itself having to adapt to the political circumstances surrounding the rise to popularity of solar energy is the new Solar Energy Research Institute (SERI) at Golden near Denver.

The proposal for such an institute was first made in legislation passed in the aftermath of the Arab oil embargo of 1973. After the idea of a single centre, relatively protected from political pressure, had been vetted and approved by the National Academy of Sciences, a competition was held to find the most suitable site.

The competition was won by a proposal from the Midwest Research Institute, a non-profit organisation which had prepared a plan based on the Golden site. However when the winner was announced, the administration said that it intended to establish four additional regional research institutes. These had never been contemplated either by Congress or by the NAS, and the fact that their siting reflected the constituency interests of key Democrat congressmen, such as Hubert Humphrey and Edward Kennedy, only reinforced concern that the political pork-barrel was at work.

After considerable dispute, and an internal inquiry under the auspices of John Deutch, head of the Office of Energy Research, it was finally agreed last month that the four regional institutes will still be developed, but will have a different role from SERI. The latter will remain the prime institution with regard to $\mathrm{R} \& \mathrm{D}$; the regional institutions will be more concerned with pushing proven solar technology out into the market place. SERI has now, albeit reluctantly, accepted this compromise. But it is also having to live closer to the DOE than it would have liked, being told what to do rather than determine its own strategy.

The director of SERI, for example, Dr Paul Rappoport, says that he is relatively happy with the present arrangements. However he does not deny that he would prefer to be working on a longer timescale than the 1985 perspective for which Energy Secretary Dr James Schlesinger is aiming.

The DOE, the utility companies, and SERI are all therefore having to cope with demands that do not grow directly out of the logic of their previous paths. And unlike countries such as the United Kingdom, in which Energy Secretary Tony Benn has consciously designed his energy strategy as an agent of social policy, what is emerging in the US is a joint strategy whose aim is to reinforce, rather than replace, the market system as the basic mechanism for the distribution of energy.

In the DOE for example, "commercialisation' has become a key word used by research planners. Thus an internal memorandum to Secretary Schlesinger suggests a strategy for bringing down the costs of photovoltaic cells by linking $R$ \& D efforts to a large scale commercial exercise which would, for a period of years, guarantee to meet the difference between the costs at which cells can be produced and the price which users are prepared to pay. At SERI, too, much of the emphasis is on finding ways of moving solar technology to the point where its development can be left to the dynamics of market pull.

\section{Environmentalists fears}

But what concerns environmentalists and others is that the increasing presence of large corporate interests in the field of solar energy could seriously distort the development of the technology away from the socially desirable towards the merely profitable. As an example, they point to plans that are rapidly gathering support in Congress to build vast solar satellites each capable of producing enough power to meet the needs of an average city. A bill proposing a feasability study

\section{Collecting solar energy in the desert}

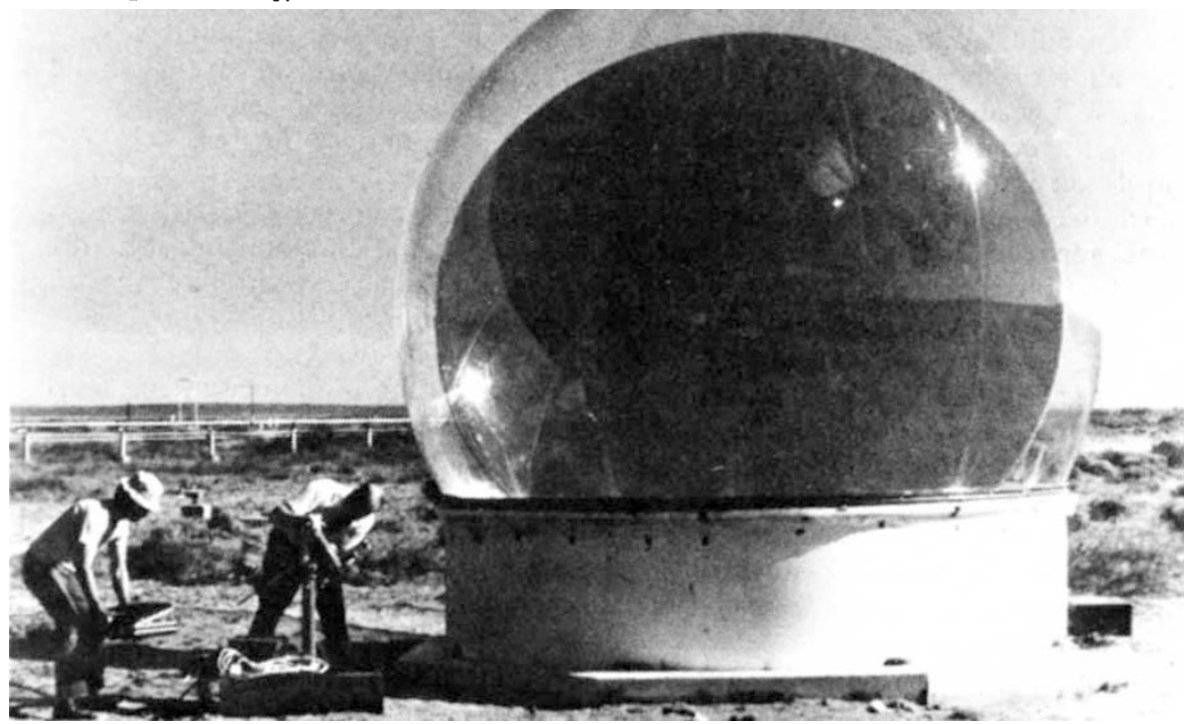

for such systems has already been introduced into the House, largely as a result of pressure from a group known as the Sunsat Energy Council, whose members include companies such as Boeing, McDonnell Douglas, Lockheed Corporation and General Electric.

Many of these firms are also closely involved in the development of large land-based solar systems. Others are concerned that utility companies are pushing for centralised power systems, rather than attempting to exploit the full potential for decentralised power production that solar energy offers.

The contrast between idealism and political realities is everywhere apparent. Thus the organisers of Sunday claim that the widespread use of solar systems "fits well into a political system that emphasises decentralisation and local control". In contrast, the president of an association of 1,300 small fuel oil producers in New England who sell and maintain solar panels admits: "we see that solar is coming, and we want to control as much of the market as we can".

Even on costs, slogans are deceptive. Great play is made of the fact that sunshine is free; yet as scientists at SERI point out, its effective conversion is far from free, and is in fact capitalintensive. Its economic advantages over other existing fuels can only be demonstrated by inserting other costssuch as environmental and health damage-into planning equations which few economists can yet effectively do.

Such contradictions are coming home tc roost in the White House itself. Last month the president's cousin, Hugh Carter, who is largely responsible for the White House budget, complained that a plan submitted by the DOE to provide hot water by solar power was "not economically justifiable at today's fuel prices." What the president will do about his own domestic arrangements is awaited with interest. $\square$ 